\title{
FORUM
}

\section{The Environmental Effects of Genetically Modified Crops Resistant to Insects}

\author{
Eliana M.G. Fontes ${ }^{1}$, Carmen S.S. Pires ${ }^{1}$, Edison R. Suji ${ }^{1}$ and Antônio R. Panizzi ${ }^{2}$ \\ ${ }^{1}$ Embrapa Recursos Genéticos e Biotecnologia, C. postal 02372, 70849.970, Brasília, DF \\ ${ }^{2}$ Embrapa-Labex-USA, National Center for Agricultural Utilization Research, USDA-ARS, 1815 North University Street, \\ Peoria, IL 61604-3902, USA
}

Neotropical Entomology 31(4):497-513 (2002)

Efeitos Ambientais de Culturas Geneticamente Modificadas Resistentes a Insetos

\begin{abstract}
RESUMO - Cultivares transgênicas de várias culturas estão sendo utilizadas em escala comercial em muitos países. A área dedicada ao cultivo com plantas transgênicas resistentes às pragas em todo o mundo alcançou 13 milhões de hectares em 2001. As cultivares transgênicas proporcionam benefícios, mas também apresentam riscos potenciais. As avaliações do seu impacto no ambiente são conduzidas antes da sua aprovação para uso comercial, como requerido pelas normas de biossegurança. Nesta revisão, serão discutidas as consequiências ecológicas potenciais do uso comercial na agricultura de cultivares geneticamente modificadas que apresentam resistência aos insetos-pragas. Também serão discutidos os impactos ambientais causados pelas mudanças nas práticas agrícolas, identificando-se falhas e oportunidades de pesquisa, considerando-se essa nova ferramenta tecnológica. Os comentários e análises serão baseados no conhecimento atual que se tem dos riscos e beneficios do uso de cultivares resistentes a insetos, geneticamente modificadas, dentro do contexto dos programas de manejo integrado de pragas tradicionais.
\end{abstract}

PALAVRAS-CHAVE: Planta transgênica, Bacillus thuringiensis, organismo não-alvo, fluxo gênico, biossegurança

\begin{abstract}
Transgenic crops are currently being cultivated on a commercial scale in many countries. The area devoted to transgenic pest resistant varieties worldwide reached 13 million hectares in 2001. These varieties offer valuable benefits but also pose potential risks. Assessments of their impact on the environment are conducted before they are approved for commercial use, as required by the regulatory biosafety frameworks. In this review, we discuss the potential ecological consequences of the commercial use in agriculture of genetically modified insect resistant crops. We also discuss the impacts caused by the change in agricultural practices, and attempt to identify gaps and possible opportunities for research, considering this new technological tool. We based our analysis and comments on the current knowledge of the risks and benefits of these genetically modified insect resistant crops, within the context of traditional insect management strategies.
\end{abstract}

KEY WORDS: Transgenic crop, $B t$ gene, non-target organism, gene flow, biosafety

In recent years, the introduction of genetically modified (GM) crops through modern biotechnology is been considered a new technological breakthrough in agriculture, only comparable to the green revolution of the early 70's. The potential impact of this technology has also been compared with the introduction in the market of synthetic insecticides and many believed that this would solve pest problems around the world. Parallel to this great expectation, the molecular breeding of cultivated plants through genetic engineering has raised a worldwide debate about their potential impact on the environment.

Since the introduction of genetically modified (GM) crops to the market in 1996 (James 2001), there has been an increasing interest on how changes in agriculture practices might indirectly affect the environment (Dale et al. 2002). The discussions on GM pest resistant crops in many parts of the world has led to questions about their potential impacts on biodiversity, particularly on their effects on non-target organisms, including insect herbivores and natural enemies, and soil microbiota. Further concern arises from the possibility of resistance development in insect pests, which could endanger important natural resources such as the bacterium Bacillus thuringiensis Berliner, a natural microbial insecticide. Another issue frequently cited as a potential risk of pest resistant GM crops is the possible movement of the inserted gene from crops to wild or weedy relatives, and the consequences of such movement.

These questions have been the subject of research for the 
past 15 years. The information raised is being used for the environmental risk assessments of GM crops, which is a fundamental procedure in the biosafety regulatory process internationally.

The objective of this article is to discuss the ecological principles and questions that have emerged from the environmental impact of this technology, and to consider the present state of knowledge about the different kinds of environmental effects of GM insect resistant crops available so far. Our review was based on diverse and consistent peerreviewed literature, which we have tried to reproduce in a style easily understood by entomologists; we have tried to avoid much of the specific details of the diverse and complex issues involved in this subject.

\section{The Market of GM Plants in the World}

The global area of genetically modified plants reached 52.6 million hectares in 2001 (James 2001). Transgenic plants expressing $B t$ toxins conferring resistance against insects were tested in the field in at least 18 crops. However, only corn, cotton and potato are commercially available (Shelton et al. 2002). In the United States, pest resistant transgenic crops have been cultivated in large areas since 1996. In 2001, approximately 13 million hectares were cultivated with $B t$ corn and $B t$ cotton, mainly in the USA and Canada (James 2001). $B t$ crops are also being cultivated in China, India, South Africa and Argentina, with a great expansion in China (Carpenter et al. 2002). Consequently, some experience is being accumulated on the commercial use of insect resistant transgenic crops.

\section{Protecting Plants from Pests - Risks and Benefits}

Plant breeders attempt to minimize the impacts of crop pests by breeding plants resistant to the attack of pests. These breeders use the natural plant genetic variation and induced mutations to select desirable traits and introduce them into cultivated plants, using a combination of classical and modern plant breeding methods.

To make crop plants resistant to the attack of insects and diseases, breeders have relied on the chemical defenses of plants. Plants produce a variety of antimicrobial or insecticidal or defensive substances that provide protection against pests. These are secondary plant metabolites that include phenolics, terpenoids and steroids (Kogan 1986).

Traditional breeding to alter the plant's chemical composition to intoxicate target herbivores is achieved through the transfer or exchange of the desired traits among sexually compatible, i.e., related plant species which share genomes that are largely homologous. On the other hand, molecular breeding through genetic engineering can use genes and gene constructs derived from completely unrelated organisms, and add them to the existing genome in an entirely novel genetic context (Regal 1994). The added novel gene constructs contain not only the desired trait, but also marker genes, promoters and terminators.

The greater diversity of genes that can be transferred by genetic engineering methods, their enhanced effectiveness, and the ability to insert the same gene into many cultivated species have led to concerns about transgenic crops. Some transgenic breeding result in pest-protective traits that are phenotypically indistinguishable from those conferred by traditional breeding methods. In addition, transgenic methods are based on a more complete knowledge of the genes that are being transferred into cultivated plants. There are cases, however, when transgenic pest-protection traits may result in plants having new phenotypes that could affect human or animal health, non-target organisms, or the weediness of crop relatives. Transgenic methods can also introduce extraneous traits when they involve marker genes, such as antibiotic resistance genes. These are concerns that are taken into consideration by the biosafety regulatory process before transgenic varieties are commercialized.

Some of the investigated potential benefits of transgenic insect resistant crops include reduced applications of broadspectrum insecticides (Carpenter et al. 2002), increased or protected yields due to season-long control of the target insect pest (Rice \& Pilcher 1998); protection of stored corn from Lepidopteran insect pests (Giles et al. 2000); and, lower mycotoxin levels due to a reduction in fungal plant pathogens associated with Ostrinia nubilalis (Hübner) feeding on corn (Munkvold et al. 1999).

Perceived disadvantages of genetically modified crops may be grouped into five categories: 1) potential impact on nontarget species; 2) potential for increased weediness; 3) increase in toxin levels in the soil; 4) exchange of genetic material between the transgenic crop and related plant species; and 5) selection for resistance among populations of the target pests.

\section{Transgenic Strategies for Plant Protection}

Characteristics. The transgenic breeding method or the DNA recombinant technology allows the transference of genes from one species to another without sexual hybridization. Plant breeding by biotechnological processes (Brasileiro \& Carneiro 1998) starts with prospecting desirable traits expressed under control of a single gene, e.g., production of a protein that could be toxic to herbivorous insects. Microorganisms and plants that produce toxins against pests have been the main source of genes for this technology. The next step in the process is the identification of the gene in charge of expressing the selected trait and then its isolation using restriction enzymes. This gene is then cloned and linked to other gene fragments to form the cassette of expression. This cassette is a piece of DNA that will be inserted into the plant to promote the expression of the desired characteristic.

Besides the gene of interest the cassette of expression is commonly comprised of a marker gene, a promoter gene and a terminator gene. The promoter gene has a central role in the gene transfer. Its function is to promote the expression of the gene of interest since many foreign genes (mainly those isolated from prokaryotes) will not express in plants. The $35 \mathrm{~S}$ promoter gene isolated from the cauliflower mosaic virus is largely used due to its strength in inducing the expression of selected genes, and because it has a constitutive character, i.e., it is expressed in all tissues of the plant. Another important gene usually present in the cassette of expression is the marker gene. It allows the selection of the transformed cells in the 
cell culture media. The most commonly used marker is the antibiotic resistance gene. In this case, the selection is made by adding to the culture media a specific antibiotic. The transformed cells that became resistant to that antibiotic will survive and the other cells will die. Biosafety concerns about the use of antibiotic resistant genes has lead researchers and the industry to avoid these genes and use new markers such as herbicide resistance and the expression of special carbohydrate (mannose) degradation enzymes. The terminator gene contained in the cassette "informs" to the cells the end of the expression code.

The last step in the transformation process is to grow the selected cells to regenerate the plant that will express and transmit the new trait to other varieties through sexual hybridization or cloning.

Insecticidal Toxins from $B$. thuringiensis $(B t)$. During sporulation $B$. thuringiensis produces crystalline inclusions that are protoxins called d-endotoxins. These structures called cry proteins, when ingested by the insect, are dissolved in the gut and cleft by digestive proteases activating the toxin. The toxin then binds to specific glycoprotein receptors on the surface of cells lining the gut, causing an imbalance in ion concentration, destroying the cells, and resulting in the death of the insect (Choma et al. 1990). In addition, some strains of $B$. thuringiensis produce "vegetative insecticidal proteins" (VIPs) before sporulation (Lacey \& Kaya 2000).

Since 1942, when E. A. Steinhaus demonstrated the potential of this bacterium for pest control, the use of $B t$ formulations increased as bioinsecticides because of its safety, been harmless to vertebrates and other non-target fauna, and because of the specificity of each cry protein which infects only a narrow range of hosts (Tanada \& Kaya 1993, Peferoen 1997). However, instability and degradation of cry proteins when exposed to ultra violet radiation and short persistence on the plant (easily washable by rain and irrigation), have constrained large adoption of $B t$ pesticides by farmers.

B. thuringienis produces a broad diversity of cry proteins with a range of around 100 holotype toxins distributed in 40 groups (cry1, cry2, etc.) each one with several subgroups and a narrow range of host (Bravo et al. 1998). This variability is being used to develop transgenic plants resistant to pest attack.

Transgenic Plants Expressing $B \boldsymbol{t}$ Toxins. Several $B t$ toxins have been inserted into crop plants to provide protection against different groups of pest insects. A brief list was presented by Jouanin et al. (1998), which we updated (Table 1). Many crops such as vegetables, forage crops, root crops, cereals, and trees are now being transformed to be protected against insects by $B t$ toxins (Shelton et al. 2002). New constructs of $B t$ toxin genes with promoters to be expressed in monocots or dicots, and in different tissues of the plant are been studied, including the integration of a native $B t$ gene into the chloroplast genome of tobacco (McBride et al. 1995). The chloroplast genome is bacterial in nature, avoiding the need of modifying the toxin gene for higher expression. Although it is still not commercially available, this technique opens new perspectives for the $B t$ plant breeding in the future.
Inhibitors of Insect Digestive Enzymes. Plants extensively produce proteins with antimetabolic activity against diverse digestive enzymes of herbivores. These proteins have either a role as part of defense strategy against herbivores or for preserving stored nutrients as proteins and carbohydrates. Genes encoding these proteins are a valuable source to enhance resistance of plants against insects and could be used in plant breeding programs.

Inhibitors of Digestive Proteases. There are four classes of protease inhibitors based on their specificity: serine, cysteine, metallo- and aspartyl-proteases. All are small proteins that bind to the insect's digestive enzymes producing an inactive complex that prevents the absorption of amino acids, leading to nutrient starvation. Consequently, these inhibitors induce death or reduction in larval growth. The protease inhibitors can also induce the over-expression of digestive enzymes affecting larval growth. Serine protein inhibitors have activity sites, which inhibit trypsin and chimotrypsin, and are effective antimetabolites against Lepidoptera and Diptera (Duan et al. 1986, Hilder et al. 1995, Xu et al. 1996, Gatehouse et al. 1997). A successful case is the cysteine protease inhibitor gene introduced into poplar to protect the plant against beetles (Leplé et al. 1995).

Inhibitor of Alfa-Amylase. The alfa-amylase inhibitor is a seed protein contained in the common bean, Phaseolus vulgaris L., and its linkage with certain amylases forming inactive complex provide seed protection against several bruchid beetles (Shade et al. 1994, Shroeder et al. 1995). However, other species of bruchids (Zabrotes subfasciatus Boh. and Acanthoscelides obtectus Say) have a protective mechanism to inactivate alpha-amylase (Ishimoto et al. 1996). The limited range of target insects makes it difficult to evaluate the real value of this gene in the protection of seeds against post-harvest pests.

Lectins. This is a heterogeneous group of proteins with carbohydrate-binding activity. They are found in many plants, in higher concentrations in storage tissues and seeds. Lectin expression genes have been inserted into several plant species which then demonstrated enhanced resistance against insects, although the way these proteins cause deleterious effects on insects is not well known (Gatehouse \& Gatehouse 2000). The well-documented anti-nutrient action and toxicity of these proteins towards mammals and birds in nature, in spite of its inactivation by cooking (Shatters 2000), have served as a baseline of an intense discussion about the biosafety of transgenic plants.

Other Genes and Traits. Transgenic expression of other proteins is also an alternative to the use of $B t$ genes. Chitinase against the beetle Orizaephilus mercator Fauvel (Jouanin et al. 1998), and cholesterol oxidase against the cotton boll weevil Anthonomus grandis Boh., are some examples of enzymes expressed by transgenes with potential effects on insect, although protective effects on plants have still not been demonstrated (Gatehouse \& Gatehouse 2000). 
Table 1. Insect-resistant transgenic plants expressing B. thuringiensis toxins.

\begin{tabular}{|c|c|c|c|}
\hline Crop plant & Toxin & Target insect & Reference \\
\hline Alfalfa & cry1Ca & Spodoptera litoralis (Boiusduval) (Lep.) & Sthrizhov et al. (1996) \\
\hline Broccoli & cry $1 \mathrm{C}$ & Plutella xylostella (L.) (Lep.) & Zhao et al. (2001) \\
\hline Cabbage & cry $1 \mathrm{Ab}$ & P. xylostella & Bhattacharya et al. (2002) \\
\hline \multirow[t]{2}{*}{ Canola } & cry $1 \mathrm{Ac}$ & $\begin{array}{l}\text { Thrichoplusia ni (Hübner) (Lep.), Spodoptera exigua (Hübner), } \\
\text { Heliothis virescens (Fabr.), Helicoverpa zea (Boddie) (Lep.) }\end{array}$ & Stewart et al. (1996b) \\
\hline & cry1Ac & P. xylostella & Ramachandran et al. (1998) \\
\hline \multirow[t]{2}{*}{ Cotton } & cry1Ab & H. virescens, H. zea & Perlak et al. (1990) \\
\hline & cry $1 \mathrm{Ac}$ and cry $2 \mathrm{Ab}$ & S. exigua, Pseudoplusia includens (Walker) (Lep.) & Adamczyk et al. (2001) \\
\hline \multirow[t]{2}{*}{ Eggplant } & cry1Ab & Leucinodes orbonalis Guenée (Lep.) & Kumar et al. (1998) \\
\hline & cry3A & Leptinotarsa decemlineata (Say) (Col.) & Jelenkovic et al. (1998) \\
\hline \multirow[t]{2}{*}{ Corn } & cry $1 \mathrm{Ab}$ & Ostrinia nubilalis (Hübner) (Lep.) & Koziel et al. (1993) \\
\hline & cry9c & O. nubilalis & Jansem et al. (1997) \\
\hline \multirow[t]{2}{*}{ Poplar } & cry1Aa & Lymantria dispar (L.) (Lep.) & McCown et al. (1991) \\
\hline & cry3Aa & Chrysomela tremulae $\mathrm{F}$. (Col.) & Cornu et al. (1996) \\
\hline \multirow[t]{3}{*}{ Potato } & cry $1 \mathrm{Ab}$ & Phthorimaea operculella (Zeller) (Lep.) & Peferoen et al. (1992), Rico et al. (1998) \\
\hline & cry $1 \mathrm{Ab}$ & Heliothis armigera (Hübner) & Chakrabarti et al. (2000) \\
\hline & cry3Aa & L. decemlineata & $\begin{array}{l}\text { Adang et al. (1993), Perlak et al. (1993) } \\
\text { Coombs et al. (2002) }\end{array}$ \\
\hline \multirow[t]{6}{*}{ Rice } & cry $1 \mathrm{Ab}$ & Chilo supressalis Walker (Lep.) & Fujimoto et al. (1993) \\
\hline & cry1B & C. supressalis & Marfa et al. (2002) \\
\hline & & Cnaphalocrosis medinalis Guenée (Lep.) & Wunn et al. (1996) \\
\hline & cry $1 \mathrm{Ac}$, cry $2 \mathrm{~A}$ and GNA & C. medinalis, Scirpophaga incertulas Walker (Hom.) & \\
\hline & & Nilaparvata lugens Stål (Hom.) & Maqbool et al. (2001) \\
\hline & cry $1 \mathrm{Ab}$ and cry1 Ac & C. supressalis & Cheng et al. (1998) \\
\hline \multirow[t]{2}{*}{ Soybean } & cry1Ac & H. virescens, H. zea & \\
\hline & & P. includens & Stewart et al. (1996a) \\
\hline \multirow[t]{9}{*}{ Tobacco } & cry1Aa & Manduca sexta (L.) (Lep.) & Barton et al. (1987) \\
\hline & cry1Ab & M. sexta & Vaeck et al. (1987) \\
\hline & cry $1 \mathrm{Ab}$ and cpTI & M. sexta & Perlak et al. (1991) \\
\hline & cry $1 \mathrm{Ab}$ & M. sexta & Williams et al. (1993) \\
\hline & cry1Ac & H.virescens, H. zea, S. litoralis & McBride et al. (1995) \\
\hline & cry1C & S. litoralis & Strizhov et al. (1996) \\
\hline & cry $2 \mathrm{~A}$ & H. armigera & Selvapandiyan et al. (1998) \\
\hline & cry $2 \mathrm{~A}$ & H. virescens, H. zea & \\
\hline & & S. exigua & Kota et al. (1999) \\
\hline \multirow[t]{2}{*}{ Tomato } & cry1Ab & H. virescens & Fischolff et al. (1987) \\
\hline & cry $1 \mathrm{Ac}$ & H. armigera & Mandaokar et al. (2000) \\
\hline
\end{tabular}

Lep = Lepidoptera; $\mathrm{Col}=$ Coleoptera Hom = Homoptera

\section{Non-target Effects of Insect Resistance}

In the scope of this review, following the definition of Dale et al. (2002), non-target effects are any undesirable effects of insect resistance GM plants on friendly organisms (unintended targets) in the environment. Non-target organisms include natural enemies, pollinators, and other non-target herbivorous that feed preferentially on the surrounding vegetation and might be affected.

Effect on Natural Enemies. Despite their apparent simplicity, agricultural systems consist of organisms that interact in food webs (Price et al. 1980). In the last 20 years the effect of host plants on higher-trophic-level organisms, such as parasitoids and predators, has been studied (Groot \& Dicke 2002). Most of the published papers have demonstrated that differences in plant traits may affect natural enemies directly. The plants are a source of water or nutrition for many species of parasitoids and predators that feed on floral or extrafloral nectar, pollen or plant sap. Consequently, changes in plant quality may affect the food source of those species.

Variation in the quality and quantity of plant secondary compounds may indirectly affect the natural enemies by reducing the nutritional suitability and palatability of their prey (Price et al. 1980, 1997). Alternatively, plant resistance traits may indirectly affect the population of natural enemies by severely depleting their supply of prey or hosts (Hoy et al. 1998, Schuler 2000). Yet plants provide not only food but also play an important role in the host searching behavior of many species of natural enemies that commonly seek herbivores on plants. Consequently, differences in plant chemicals produced constitutively or in response to herbivory may alter the attractiveness of the plant to some species of entomophagous arthropods (Vinson 1976, Lewis \& Takasu 1990).

Despite many examples that have shown that plant breeding affects the effectiveness of biological control agents (Groot \& Dicke 2002), conventional plant breeding programs have largely ignored natural enemies of pests in their protocols. A change in this tendency has been observed in regard to GM insect resistant crops (Schuler 2000). The 
potential effects of insect resistant GM plants on ecological disruption of food webs and consequent effects on natural biological control has been discussed by Hoy et al. (1998) and Groot \& Dicke (2002). Genetic engineering capability to produce precise genetic alterations increases confidence that unintended changes in the genome have not occurred. However, precise genetic characterization does not ensure that all ecologically important aspects of the phenotype can be predicted for the environments into which an organism will be introduced (Tiedje et al. 1989).

It is reasonable to point out that the potential impacts on natural enemies associated with the plants produced by conventional and transgenic methods fall into the same general categories. Hilbeck (2002) discusses extensively the genetic engineering and conventional breeding for host plant resistance and the possible non-target effects of both breeding methods. She emphasizes that the season-long and high-level expression of $B t$ toxins on crops may have more three-trophic effects than conventionally bred crops. It is important to remember that any human interference to protect crops from pests will have some negative impact on those arthropods that depend on those pests (Hoy et al. 1998, Schuler 2000), and on the overall biological community (Shelton et al. 2002).

Natural enemies might be affected by GM plants in several ways: directly through feeding on the plant tissues (e.g., pollen) that express the gene product (Bt protein, transgenic lectin or proteinase inhibitors); feeding on prey or host that feed on GM plants; and indirectly through the interference with the production of volatile chemicals responsible for the plant's attractiveness to natural enemies. Additionally, the most obvious way the GM plants can affect natural enemies is by deploying the population of their prey or hosts. This applies to all pest control methods and will be more severe for specialized natural enemies that feed exclusively on the target insect of the pest resistant GM plant. Compared to predators, parasitoids that are relatively host-specific will probably be more affected by host population depletion.

The impact of transgenic plants resistant to insects on the population dynamics of natural enemies will depend on several factors, including the expression level of the transgene, the specificity of the transgene product, and the tissue specificity of the transgene (Schuler 2000). The expression level that induces pest mortality rates close to $100 \%$, observed on most $B t$ plants, results in host depletion for parasitoids specific to the target pest and in a reduction in prey or host for generalist natural enemies, when compared to populations in unsprayed non-Bt crops (Schuler 2000). In some cases, a partial plant resistance could be advantageous because synergistic interactions between partially resistant plants and natural enemies are possible (Hoy et al. 1998). The specificity of the protein expressed by the transgene and the plant tissue where the gene product will be expressed determines the possibilities of any direct negative effects on non-target organisms.

The impact of transgenic plants resistant to insect on the population dynamics of natural enemies will also depend on the plant species in question, on the geographical location in which the GM plant is cultivated, and on the management of the crop (Schuler 2000). For example, crop plants with different life cycles (annual versus perennial) will differ in their associated arthropod communities. The impact of the removal of one target pest species on the non-target fauna will differ between the two crops. Additionally, different pest and non-target species occur in different parts of the world. Therefore, risk assessment results obtained in one country do not necessarily apply to other geographical regions.

In the last seven years, some studies have examined the safety of transgenic crops, especially the effect of these plants on the fitness of non-target organisms (Groot \& Dicke 2002, Obriky et al. 2001). Most of the available risk assessment information relates to insect-resistant transgenic plants containing genes coding for $B t$ toxins (corn, cotton, and potato). However, the points discussed here also apply to other insect resistant GM plants.

We analyzed 21 research reports where results of 41 studies were presented (Table 2). Twenty of them were conducted in the laboratory and 21 reported field sampling of natural enemies. In some of the laboratory studies (14 cases), no adverse effects of $B t$ plants were observed. In six other studies, negative effects on fitness of certain natural enemies were reported. In 14 of 21 field studies, the authors found no differences in density of natural enemies between $B t$ and non$B t$ crops, whereas in seven cases lower density of natural enemies was registered in the $B t$ fields. From the 21 reports, only two were related to resistant traits other than Bt-protein. Birch (1999), working with transgenic lectin (GNA) expressing plants, found that GNA exhibited sublethal effects on aphids, in turn affecting reproduction and longevity of beneficial coccinellid predators. Bell et al. (2001) evaluated the effect of trypsin inhibitor expressed in potato leaves on the gregarious ectoparasitoid Eulophus pennicornis (Nees) and found a decrease in parasitism rates on hosts fed on GM potato leaves. Only one study (Schuler et al. 1999b) evaluated the possible effects of GM plants on the searching behavior of parasitoids. In this study the authors found that $B t$-oilseed rape leaves, in the presence of $B t$ non-resistant larvae of Plutella xylostella (L.) (Lepidoptera: Plutelidae), were less attractive to Cotesia plutellae (Kurdjumov) (Hymenoptera: Braconidae) due to the low leaf consumption rate.

The studies of Hilbeck et al. (1998a, b; 1999) and Bell et al. (2001), despite their non-conclusive results, demonstrated the importance of experiments where the three-way interaction among plants, $B t$-protein, and herbivores can be evaluated. They found highest mortality of the natural enemy when the prey's food source was GM plants compared to protein-incorporated diets. They observed highest mortality of the predator Crysoperla carnea (Stephens) (Hilbeck et al. 1998a, b; 1999), and low parasitism rate of the ectoparasitoid E. pennicornis (Bell et al. 2001) when the prey's food source was the GM plant compared to protein-incorporated artificial diets. Hilbeck (2002) argued that this may be due to the fact that higher-trophic-level organisms might receive the compound in an altered form due to processing by the herbivores.

The data available in the literature regarding the impact of $B t$-crops on natural enemies are inconclusive. Most laboratory studies have concentrated on some but not all aspects of the fitness of insect predators. These experiments generally did not cover the entire larval period, and were 
Table 2. Effects of insect resistant GM plants on natural enemies.

\begin{tabular}{|c|c|c|c|c|}
\hline Natural enemies & $\begin{array}{l}\text { Host/food source/ } \\
\text { Expressed protein }\end{array}$ & $\begin{array}{l}\text { Location } \\
\text { of study }\end{array}$ & $\begin{array}{l}\text { Biological parameters } \\
\text { and results }\end{array}$ & References \\
\hline \multicolumn{5}{|l|}{ Coleoptera } \\
\hline \multicolumn{5}{|l|}{ Carabidae } \\
\hline Lebia grandis Hentz & Larvae/Bt-potato (cry3A) & $\mathrm{L}^{1}$ & Prey consumption $\left(\mathrm{NA}^{\mathrm{a}}\right)$ & Riddick \& Barbosa (2000) \\
\hline \multirow[t]{3}{*}{ Carabidae fauna } & $B t$-corn $[(\operatorname{cryIA}(\mathrm{b})]$ & $\mathrm{F}^{2}$ & $\begin{array}{l}\text { Diversity (NA) } \\
\text { Density (NA) }\end{array}$ & Lozzia (1999) \\
\hline & $B t$-corn $[(\operatorname{cryIA}(\mathrm{b})]$ & $\mathrm{F}$ & $\begin{array}{l}\text { Density }<\text { non-spray field }{ }^{\mathrm{b}} \\
\text { Density }=\text { spray field }^{\mathrm{c}}\end{array}$ & Brazil/CTNBio (1999a) ${ }^{\alpha}$ \\
\hline & $B t-\operatorname{corn}[(\operatorname{cryIA}(\mathrm{b})]$ & $\mathrm{F}$ & Density = non-spray field & Brazil/CTNBio $(1999 b)^{\beta}$ \\
\hline \multicolumn{5}{|l|}{ Coccinelidae } \\
\hline \multirow[t]{2}{*}{$\begin{array}{l}\text { Hippodamia convergens } \\
\text { Guérin-Méneville }\end{array}$} & Aphids/Bt-potato (cry3A) & $\mathrm{L}$ & $\begin{array}{l}\text { Development (NA) } \\
\text { Survivorship (NA) } \\
\text { Reproduction (NA) } \\
\text { Prey consumption (NA) }\end{array}$ & Dogan et al. (1996) \\
\hline & $B t$-corn $[(\operatorname{cry} 1 \mathrm{~A}(\mathrm{~b})]$ & $\mathrm{F}$ & Density (NA) & Pilcher et al. (1997) \\
\hline \multirow{2}{*}{$\begin{array}{l}\text { Coleomegilla maculata (De } \\
\text { Geer) }\end{array}$} & $B t$-corn $[(\operatorname{cry} 1 \mathrm{~A}(\mathrm{~b})]$ & $\mathrm{F}$ & Density (NA) & Pilcher et al. (1997) \\
\hline & $B t$-corn pollen $[(\operatorname{cry} 1 \mathrm{~A}(\mathrm{~b})]$ & $\mathrm{L}$ & $\begin{array}{l}\text { Development (NA) } \\
\text { Survivorship (NA) }\end{array}$ & Pilcher et al. (1997) \\
\hline Coccinella septempunctata (L.) & $B t$-corn $[(\operatorname{cry} 1 \mathrm{~A}(\mathrm{~b})]$ & $\mathrm{F}$ & Density $=$ non spray field & Bourguet et al. (2002) \\
\hline Adalia bipunctata (L.) & Aphids/GNA-potato & $\mathrm{L}$ & $\begin{array}{l}\text { Fecundity }\left(\mathrm{A}^{\mathrm{d}}\right) \\
\text { Eclosion rate }(\mathrm{A}) \\
\text { Female longevity }(\mathrm{A})\end{array}$ & Birch et al. (1999) \\
\hline Coccinelidae fauna & $B t$-corn $[(\operatorname{cryIA}(\mathrm{b})]$ & $\mathrm{F}$ & Density $=$ non spray field & Brazil/CTNBio (1999b) \\
\hline \multicolumn{5}{|l|}{ Dermaptera } \\
\hline \multicolumn{5}{|l|}{ Forficulidae } \\
\hline \multirow[t]{2}{*}{ Doru luteips (Scudder) } & $B t$-corn $[(\operatorname{cryIA}(\mathrm{b})]$ & $\mathrm{F}$ & $\begin{array}{l}\text { Density }>\text { spray field } \\
\text { Density }>\text { non-spray field }\end{array}$ & Brazil/CTNBio (1999a) \\
\hline & $B t$-corn $[(\operatorname{cryIA}(\mathrm{b})]$ & $\mathrm{F}$ & Density $=$ non-spray field & Brazil/CTNBio (1999b) \\
\hline \multicolumn{5}{|l|}{ Diptera } \\
\hline \multicolumn{5}{|l|}{ Syrphidae } \\
\hline Syrphus corollae (Meigen) & $B t$-corn $[(\operatorname{cry} 1 \mathrm{~A}(\mathrm{~b})]$ & $\mathrm{F}$ & Density $=$ non-spray field & Bourguet et al. (2002) \\
\hline \multicolumn{5}{|l|}{ Hemiptera } \\
\hline \multicolumn{5}{|l|}{ Anthocoridae } \\
\hline Orius majusculus (Reuter) & Thrips/Bt-corn $[(\operatorname{cry} 1 \mathrm{~A}(\mathrm{~b})]$ & $\mathrm{L}$ & $\begin{array}{l}\text { Development (NA) } \\
\text { Survivorship (NA) }\end{array}$ & Zwahlen et al. (2000) \\
\hline O. tristicolor (White) & $B t$-potato leaves (cry IIIA) & $\mathrm{L}$ & Longevity (NA) & Armer et al. (2000) \\
\hline \multirow[t]{3}{*}{ O. insidiosus Say } & $B t$-corn pollen $[(\operatorname{cry} 1 \mathrm{~A}(\mathrm{~b})]$ & $\mathrm{L}$ & $\begin{array}{l}\text { Development (NA) } \\
\text { Survivorship (NA) }\end{array}$ & Pilcher et al. (1997) \\
\hline & $B t$-corn $[(\operatorname{cry} 1 \mathrm{~A}(\mathrm{~b})]$ & $\mathrm{F}$ & Density $=$ non-spray field & Bourguet et al. (2002) \\
\hline & $B t$-corn $[(\operatorname{cry} 1 \mathrm{~A}(\mathrm{~b})]$ & $\mathrm{F}$ & Density (NA) & Pilcher et al. (1997) \\
\hline \multicolumn{5}{|l|}{ Lygaeidae } \\
\hline Geocoris spp. & $B t$-potato leaves (cry IIIA) & $\mathrm{L}$ & Longevity (NA) & Armer et al. (2000) \\
\hline \multicolumn{5}{|l|}{ Miridae } \\
\hline Lygus hesperus Knight & $B t$-potato leaves (cry IIIA) & $\mathrm{L}$ & Longevity (NA) & Armer et al. (2000) \\
\hline \multicolumn{5}{|l|}{ Nabidae } \\
\hline Nabis spp. & Bt-potato leaves (cry IIIA) & $\mathrm{L}$ & Longevity (NA) & Armer et al. (2000) \\
\hline Predator Hemiptera fauna & $B t$-corn $[(\operatorname{cryIA}(\mathrm{b})]$ & $\mathrm{F}$ & Density $=$ non-spray field & Brazil/CTNBio (1999b) \\
\hline
\end{tabular}


Table 2. Continued...

\begin{tabular}{|c|c|c|c|c|}
\hline \multicolumn{5}{|l|}{ Hymenoptera } \\
\hline \multicolumn{5}{|l|}{ Braconidae } \\
\hline Cotesia plutellae (Kurdjumov) & $\begin{array}{l}\text { Bt-susceptible larvae/ } \\
\text { Bt-oil seed rape (cry 1Ac) } \\
\text { Bt-resistant larvae/ } \\
\text { Bt-oil seed rape (cry 1Ac) } \\
\text { Bt-susceptible larvae/ } \\
\text { Bt-oil seed rape leaves (cry 1Ac) } \\
\text { Bt-resistant larvae/ } \\
\text { Bt-oil seed rape leaves (cry 1Ac) }\end{array}$ & $\mathrm{L}$ & $\begin{array}{l}\text { Emergence rate (A) } \\
\text { Emergence rate (NA) } \\
\text { Attraction (A) } \\
\text { Attraction (NA) }\end{array}$ & Schuler et al. (1999a) \\
\hline Diaeretiella rapae (McIntosh) & $\begin{array}{l}\text { Aphids/ } \\
\text { Bt-oil seed rape (cry 1Ac) }\end{array}$ & $\mathrm{L}$ & Parasitism rate (NA) & Schuler et al. (1999b) \\
\hline $\begin{array}{l}\text { Macrocentrus grandii Goid } \\
\text { Eulophidae }\end{array}$ & $B t$-corn (cry $1 \mathrm{Ab})$ & Eulophidae & Parasitism rate (NA) & Orr \& Landis (1997) \\
\hline Eulophus pennicornis (Nees) & $\begin{array}{l}\text { Larvae/trypsin } \\
\text { inhibitor-potato (CpTI) } \\
\text { Larvae/CpTI-artificial diet }\end{array}$ & $\mathrm{L}$ & $\begin{array}{l}\text { Parasitism rate (A) } \\
\text { Development (NA) } \\
\text { Parasitism rate (NA) } \\
\text { Development (NA) }\end{array}$ & $\begin{array}{l}\text { Bell et al. (2001) } \\
\text { Bell et al. (2001) }\end{array}$ \\
\hline \multicolumn{5}{|l|}{ Icheneumonidae } \\
\hline Erioborus terebrans (Grav.) & $B t$-corn (cry $1 \mathrm{Ab})$ & $\mathrm{F}$ & Parasitism (NA) & Orr \& Landis (1997) \\
\hline \multicolumn{5}{|l|}{ Sphecidae } \\
\hline Stictia sp. & $B t$-corn $[(\operatorname{cryIA}(\mathrm{b})]$ & $\mathrm{F}$ & $\begin{array}{l}\text { Density }<\text { non spray field } \\
\text { Density }=\text { spray field }\end{array}$ & Brazil/CTNBio (1999a) \\
\hline \multicolumn{5}{|l|}{ Tachinidae } \\
\hline Lydella thompsoni (Herting) & $B t$-corn $[(\operatorname{cry} 1 \mathrm{~A}(\mathrm{~b})]$ & $\mathrm{F}$ & Parasitism rate $(A)$ & Bourguet et al. (2002) \\
\hline $\begin{array}{l}\text { Pseudoperichaeta nigrolineata } \\
\text { (Walker) } \\
\text { Neuroptera }\end{array}$ & $B t$-corn $[(\operatorname{cry} 1 \mathrm{~A}(\mathrm{~b})]$ & $\mathrm{F}$ & Parasitism rate $(A)$ & Bourguet et al. (2002) \\
\hline \multicolumn{5}{|l|}{ Chrysopidae } \\
\hline Chrysopidae fauna & $B t$-corn $[(\operatorname{cry} 1 \mathrm{~A}(\mathrm{~b})]$ & $\mathrm{F}$ & Density (NA) & Pilcher et al. (1997) \\
\hline \multirow[t]{6}{*}{ Chrysoperla carnea (Stephens) } & Larvae/Bt-corn $[(\operatorname{cry} 1 \mathrm{~A}(\mathrm{~b})]$ & $\mathrm{L}$ & $\begin{array}{l}\text { Survivorship (A) } \\
\text { Development (A) }\end{array}$ & Hilbeck et al. (1998a) \\
\hline & $B t$-artificial diet $[(\operatorname{cry} 1 \mathrm{~A}(\mathrm{~b})]$ & $\mathrm{L}$ & $\begin{array}{l}\text { Survivorship (A) } \\
\text { Development (A) }\end{array}$ & Hilbeck et al. (1998b) \\
\hline & $\begin{array}{l}\text { Larvae/ Bt-artificial diet } \\
{[\text { cry } 1 \mathrm{~A}(\mathrm{~b}) / \text { cry } 2 \mathrm{~A}]}\end{array}$ & $\mathrm{L}$ & $\begin{array}{l}\text { Survivorship (A) } \\
\text { Development (A) }\end{array}$ & Hilbeck et al. (1999) \\
\hline & Aphids/Br-corn [(cry1A(b)] & $\mathrm{L}$ & $\begin{array}{l}\text { Development (NA) } \\
\text { Survivorship (NA) }\end{array}$ & Lozzia et al. (1998) \\
\hline & $B t$-corn pollen $[(\operatorname{cry} 1 \mathrm{~A}(\mathrm{~b})]$ & $\mathrm{L}$ & Development (NA) & Pilcher et al. (1997) \\
\hline & $B t$-corn $[(\operatorname{cry} 1 \mathrm{~A}(\mathrm{~b})]$ & $\mathrm{F}$ & Density $=$ non-spray field & Bourguet et al. (2002) \\
\hline Hemerobius sp. & $B t$-corn $[(\operatorname{cryIA}(\mathrm{b})]$ & $\mathrm{F}$ & Density $<$ spray field & Brazil/CTNBio (1999a) \\
\hline Beneficial arthropofauna & $B t$-cotton & $\mathrm{F}$ & $\begin{array}{l}\text { Density }<\text { spray field } \\
\text { Density }<\text { non spray field }\end{array}$ & Greenpeace Report (2002) \\
\hline Predator fauna & $B t$-cotton & $\mathrm{F}$ & Density (NA) & Greenpeace Report (2002) \\
\hline Beneficial entomofauna & $B t$-cotton & $\mathrm{F}$ & Density (NA) & Cui \& Xia (2000) \\
\hline Parasitoid fauna & $B t$-cotton & $\mathrm{F}$ & Density (A) & Cui \& Xia (2000) \\
\hline Predator fauna & Bt-potato cry3A & $\mathrm{F}$ & Density (NA) & Riddick et al. (2000) \\
\hline
\end{tabular}

${ }^{1} \mathrm{~L}=$ laboratory, ${ }^{2} \mathrm{~F}=$ field, ${ }^{\mathrm{N}} \mathrm{NA}=$ non affected, ${ }^{\mathrm{b}}$ non-spray field $=$ conventional crop field without insecticide control, ${ }^{\mathrm{c}}$ spray field $=$ conventional crop with insecticide control, ${ }^{\mathrm{d}} \mathrm{A}=$ affected, ${ }^{\mathrm{a}}$ Report submitted to the National Technical Biosafety Commission (CTNBio) by Monsanto do Brazil - File number: 01200.002995/99-54, ${ }^{b}$ Report submitted to the National Technical Biosafety Commission (CTNBio) by Syngenta Seeds Ltd. - File number: 01200.002109/2000-04.

conducted with few individuals. In many cases, the protein doses used in the experiments were much higher than those found in the plant tissue in the field. In addition, most of the field trials were conducted on a small scale, and over a relatively short period of time. One exception is the work by Hoy et al. (1998) that reported a series of results of field 
sampling in $B t$ potatoes systems, and showed that the diversity of arthropod species and densities of predators and parasitic Hymenoptera increased with the use of transgenic potato varieties. Their overall conclusion was that transgenic resistance, by controlling primary pests without insecticides, could preserve biological control agents that suppress secondary pests (Riddick \& Barbosa 2000, Riddick et al. 2000). Nevertheless, long-term field studies are generally limited by funding as well as the interest in moving products into the market (Shelton et al. 2002).

Effect on Non-Target Lepidoptera. Many species of Lepidoptera, both target and non-target, are likely to be directly susceptible to the $B t$ toxins. Studies on the ecological interactions of $B t$ insecticide sprays have documented some effects on non-target organisms. For example, as summarized by Obrycki et al. (2001), Tyria jacobaeae (L.), a beneficial lepidopteran introduced into North America for biological control of the weed tansy ragwort, increased mortality of $4^{\text {th }}$ and $5^{\text {th }}$ instars after feeding on tansy ragwort leaves dipped in $B t$, in laboratory bioassays (James et al. 1993). Bt sprays can affect non-target Lepidoptera from up to 30 days after spraying (Johnson et al. 1995). Furthermore, a reduction in lepidopteran species richness was found two years after forest plots were sprayed with Bt (Miller 1990).

Likewise, many species of Lepidoptera or Coleoptera (depending on the type of $B t$ toxin expressed), both target and non-target, are likely to be susceptible to the $B t$ toxins produced by transgenic crops. Losey et al. (1999) showed that the larvae of the monarch butterfly, Danaus plexippus (L.), living in weeds near corn fields, could be affected adversely by $B t$ corn pollen drifting onto the foliage of plant species explored by the butterfly. These results have been questioned on the basis that they came from small-scale laboratory assays with high levels of toxin expressed in no-choice tests. Indeed, recent studies suggest that risks posed by current corn crops incorporating the $B t$ toxin genes to monarch butterflies are not likely to be significant (Sears et al. 2001). These studies show that, while $B t$ pollen does have some toxic effects when fed to butterfly larvae, the pollen densities likely to be encountered in the field are too low to pose a risk to monarch larvae. However, another study showed that low concentrations of pollen from event $176 B t$ corn, dramatically reduced growth rates among black swallowtail caterpillars, Papilio polyxenes F., in field tests (Zangerl et al. 2001). An earlier study (Wraight et al. 2000) noted that a widely used $B t$ corn-containing event 810 , had no adverse effect on black swallowtails living on weeds near cornfields. From these results, it is reasonable to infer that a careful event selection is advisable in the development of pestprotected crops, and that research is needed on the impact of $B t$ varieties on non-target species.

Effects on Bees. The proteins present on commercial formulation of $B$. thuringiensis have being considered nontoxic against bees (Atkins et al. 1981, Arpaia 1996, Malone et al. 2001). However, different proteinase inhibitors have shown different effects on performance and behavior of worker honeybees, Apis mellifera L. (Picard-Nizou et al. 1997, Girard et al. 1998, Malone et al. 2001). The proteins inducing resistance to pest cowpea trypsin inhibitor and b1,3 glucanase negatively affect the behavior of honeybees (Picard-Nizou et al. 1997) but three proteinase inhibitors, suitable for incorporation into oilseed rape, did not affect bee behavior and caused no short-term mortality (Girard $e t$ al. 1998). These results showed that a case-by-case analysis is needed when evaluating the effect of proteinase inhibitors on learning performance of bees (Girard et al. 1998). In addition, it is necessary to test the different protein inducing resistances to insects on other bee species because, in a diverse group such as bees, it is possible that different species present different susceptibilities to these insecticidal molecules.

Caution is needed on the interpretation of results of small sets of laboratory studies of insect resistant crops, which are conducted under artificial condition, and have minor ecological relevance. Laboratory conditions do not always reproduce the complex mechanisms by which plants affect natural enemies and the detailed interactions of food webs. Furthermore, field surveys with a focus on diversity and abundance of species are needed to understand the effect of insect resistant GM crops on arthropod communities.

\section{Fate and Consequences of Insecticidal Toxins in Soil}

Bacillus thuringiensis $(B t)$ insecticides have been used for more than 30 years and they are generally considered safe for the environment. This is probably because $B t$ does not survive or grow well in natural habitats such as soil and its spores are rapidly inactivated by ultraviolet radiation (Stotzky 2002). However, when the genes that code for the production of insect toxins are genetically engineered into plants, the toxins continue to be synthesized during the growth of the plant and are present throughout the whole life cycle (Saxena \& Stotsky 2000). There are other differences between $B t$-insecticides and transgenic $B t$ plants, including the $B t$ toxin mode of action (Hilbeck 2002), that make it necessary to verify the possible impact of $B t$ crops on the soil environment, particularly on the soil microbiota. Deviations in the numbers and kinds of soil organisms may influence the fertility considerably, for example by decreasing the ability to retain water and nutrients (Christensen 1989).

Genetically modified plants that produce $B t$ toxins may release these proteins into the environment when the plants are incorporated into the soil. It has also been shown that some toxins will be released to the soil from root exudates during the entire growth of a Bt crop (Saxena \& Stotzky 2000). In this case, a question is raised whether an increasing amount of $B t$ toxins in soils could result in novel exposure of soil organisms to these toxins, with potential negative non-target effects. A series of studies has investigated the fate of the $B t$ toxins in the soil environment and their effect on soil organisms (Stotzky 2000). The toxins released in root exudates and upon disintegration of transgenic crop residues are adsorbed rapidly, bound to elements of the soil (clay particles, humic acids) and stabilized. In this case, only briefly they will be in a free state, susceptible to rapid degradation (Saxena \& Stotzky 2000, Stotzky 2002).

The cry $1 \mathrm{Ab}$ toxin from transgenic corn released in root 
exudates persists in the rhizosphere and can be active for hundreds of days (Saxena et al. 1999). These authors investigated the effect of cry1 $\mathrm{Ab}$ toxin released in the root and from biomass of $\mathrm{Bt}$ corn in the total number of earthworms, nematodes, protozoa, bacteria and fungi. Results suggested that degradation of biomass of $B t$-corn is non toxic to a variety of species used as models (US EPA 2000).

The above studies determining rates of degradation of cry proteins in soil have been of sufficient duration, and were performed under adequate conditions. However, they were essentially developed in soil microcosms. Head et al. (2002) investigated what happens to $B t$ toxins released into the soil from $B t$ crops under field conditions, in the state of Arizona (USA). They collected soil samples from within and outside fields where insect-resistant transgenic cotton encoding the cry1Ac gene had been grown and subsequently incorporated into the soil by post-harvest tillage for 3-6 consecutive years. These samples were analyzed by enzymatic and bioassay tests for the levels of cry1Ac protein. They found no detectable cry 1 Ac protein in any of the soil samples collected from within or outside the Bt-cotton fields.

Other studies including analyses of different types of soils under $B t$-crops cultivation are necessary to clarify the contrasting differences observed in the persistence of $B t$ cry $1 \mathrm{Ac}$ protein between laboratory assays and field observations. Moroever, more information on the effect on soil microbiota is needed, including possible interference with nutrient cycles and effects on ecosystem functions, although these kinds of data are still very difficult to obtain.

\section{Change in Persistence or Invasiveness of the Crop}

One of the questions most frequently raised is how the longterm performance of an insect-resistant GM crop can be predicted, as the addition of the insect resistance trait can make these plants highly competitive to the point that they can become weeds. This possibility has been investigated with a focus on how the fitness of a plant species may be altered by small changes in its genome. Ramachandran et al. (2000) compared the competitive ability of an insect-resistant transgenic oilseed rape variety with a non-transgenic oilseed rape variety in seed mixtures. The transgenic variety was competitively superior when the two varieties were subject to selection pressure in the form of herbivory by the diamondback moth, in greenhouse experiments and in field plots. In a similar study, Stewart et al. (1997) showed that, where suitable habitat is available, there is a likelihood of increased fitness in oilseed rape varieties expressing $B t$ transgenes.

However, this does not mean that the crop will necessarily become a weed, as weediness is a combination of traits such as persistence of overwintering seeds, the production of biomass, and offspring production and survival (Williamson 1993). To become a weed, the crop plants must acquire several traits that make them as competitive as the weeds in natural habitats, and these traits are controlled by a group of genes. Some authors argue that cultivated plants do not possess weed characteristics and the addition of only one gene to their genome is unlikely to provide the aggressive properties that typify weedy plants (Baker 1974, Luby \& McNichol 1995). Other authors think that small genetic changes can cause large ecological alterations (Fitter $e t$ al. 1990, Williamson et al. 1990). Besides, some cultivated plants are known to possess invasive characteristics and are even considered weeds in some circumstances, such as the grass Brachiaria decumbens Stapf, in Brazil. Experience with traditional plant breeding has shown that plant protection against herbivores may tremendously increase seed production. This experience is an indication that insect resistant traits could have significant effects on persistence and invasiveness, and that insect resistant crop varieties should continue to have a rigorous caseby-case risk assessment.

Studies on the comparison between transgenic and nontransgenic crops also consider that any additional genetic material, which provides a benefit, will also carry a metabolic cost (Hails et al. 1997). The genetic baggage hypothesis (Regal 1988) predicts that, in the absence of selection pressure, which causes the transgenic plant to be favored, the additional cost of metabolising the detoxifier could cause the transgenic to be less competitive than the wild type. Other considerations related to the cost of transgenes refer to the uncontrolled position in which the genes have been integrated into the genome, and the possibility that some traits may result in features, which will be of selective advantage in particular habitats (Hails et al. 1997).

\section{Transfer of Insect Resistance to Weeds or Feral/ Wild Plants}

It is known that in nature there is a genetic flow among plants of the same species and among plants of related species. There is a body of scientific evidence that genetic material introduced into certain species of crops will recombine with related weed species (Ellstrand 1999, Dale et al. 2002). Gene flow from crops to wild relatives is often cited as a potential risk in the commercialization of transgenic crops, based on the possibility that the introduced genes may be transferred by pollen to wild or weedy relatives and may produce offspring that will become more weedy or invasive.

The exchange of genes between weeds and crops is a natural phenomenon, but genetic engineering raises additional concerns because it enables the introduction into the ecosystem of genes that confer novel fitness-related traits. Furthermore, it allows novel genes to be introduced into many diverse types of crops, each with its own specific potential to outcross. Snow (2002) reported the results of a recent workshop held at the Ohio State University ${ }^{1}$. The studies showed that transgenes disperse and become incorporated into the genomes of other species in the same manner as do other crop genes and that gene flow can be very widespread. It is now evident that some crops can pass genes to a wild relative even when those genes are carried on unshared (nonhomologous) chromosomes. Snow (2002) also reported that a range of possible fitness costs and benefits has been

${ }^{1}$ The Scientific Methods Workshop on Ecological and Agronomic Consequences of Gene Flow from Transgenic Crops to Wild Relatives, March-5-6, 2002, Ohio State University, Columbus, OH. 
associated with particular GM traits, and that under some conditions, single or multiple transgenes will not have any detectable effect on the survival or reproduction of wild or weedy species. If there are effects, they may be difficult to detect unless weed populations are released from strongly limiting factors such as drought stress, salinity or herbivores.

This means that newly introduced genes could disperse into nearby populations, bringing new phenotypic traits such as resistance to insects, diseases, herbicides or harsh growing conditions. Data presented at the OSU meeting, indicated that wild sunflowers containing a $B$. thuringiensis gene for lepidopteran resistance can result in a large production of seeds. As Snow (2002) puts it, "when novel genes spread to free-living plant population, they have the potential to create or exacerbate weed problems by providing novel traits that allow these plants to compete better, produce more seeds and become more abundant."

Enhanced understanding of this process and, more importantly, of the impact of crop gene introgression into populations growing on roadsides, field margins, or uncultivated areas is needed as GM crops continue to be adopted. In view of these results, it becomes necessary to raise information about gene flow from transgenic plants to wild and weedy species in Brazil, aiming at the elaboration of regulatory measures to reduce the probability of unexpected and undesirable events.

\section{Development of Resistance to $B t$ Toxins in Pests}

Historically, pests have rapidly adapted to the techniques used to control them. The experience with chemical pesticides has proven to be disappointing, as pests quickly evolved resistance to them (Raymond et al. 1991, Gould 1991). More recently, several studies have shown that pests can also adapt to toxins produced by the bacteria $B$. thuringiensis under field and laboratory conditions, including resistance to $B t$ transgenic crops (Tabashnik 1994, Obryki et al. 2001).

One of the greatest concerns is that the widespread use of $B t$ crops could lead to the evolution of a number of important pest insects that are resistant to the $B t$ biopesticides. That is of particular concern to organic farmers because they use $B$. thuringiensis as a natural pesticide. Development of resistance to $B t$ crops among population of serious pests also brings concerns to the long-term use of the technology itself, as it may lose its effectiveness as a tool to control these pests.

Several strategies for resistance management have been proposed to delay the chances of pest population adaptations to $B t$ crops (Gould 1998). The most widely used is the highdose-refuge strategy, which has been implemented in North America (Alstad \& Andow 1995). In general, it is recommended that a $20-50 \%$ refuge area be planted with non$\mathrm{GM}$ varieties. In the case of $B t$ corn, it is recommended that a minimum of $20 \%$ of the area be planted with conventional varieties; and in fields where $B t$ corn is planted where cotton has been previously cultivated, at least $50 \%$ of the area must be planted with conventional varieties of corn, to avoid the development of insect pest populations resistant to $\mathrm{Bt}$ (Cannon 2000).

The strategy favored by the industry of producing transgenic varieties expressing high doses of different toxins, associated with the tactics of refuges, seemed at first to be a good idea. This strategy, however, was not prove to be efficient, due to factors such as polyphagy among insect pests that also feed on other plants including weeds, or to the movement among different cultivated fields by some insect pests. When the pests move to non-transgenic fields they are exposed to low to moderate doses of the toxin, which prevents the desirable effects of high-dose exposure (Gould 1998). Another approach to delay the evolution of resistance much more effectively is the use of additional pesticide gene, called transgene pyramiding. The new generation of GM pest resistance crops already contain two insecticidal genes. The cotton variety sGK commercially available in China contain the cry $1 \mathrm{~A}$ gene and the $\mathrm{CpT} 1$, the cowpea trypsin inhibitor gene (Shelton et al. 2002).

Implementing resistance management practices when a pest protection substance or its functional equivalent are providing effective pest control, or when there is a threat to the utility of existing uses of the pest protection substance (e.g., Bt proteins) is crucial for obtaining the greatest benefits from pest resistance transgenic crops, and for allowing the continued use of $B$. thuringiensis biopesticides.

\section{Concluding Remarks and Future Perspectives}

The use of toxin by plants for defense against pests is a common phenomenon in nature. There is good evidence from traditional breeding varieties that plant resistance can reduce the use of broad-spectrum pesticides (NRC 2000), as it allows naturally occurring pest predators and parasites to act and suppress secondary pest populations (Hoy et al. 1998). Science-based solutions to some difficulties have yet to be sought to achieve the ecological benefits of GM pest resistant crops. Among them is the incompatibility of the high concentration and presence of the pesticidal toxin in all parts of the plant during the entire season. This fails to comply with the very principle of integrated pest management (IPM), which predicts the application of control measurements only when pest populations reach the economic injury level. It is likely that in the future, greater attention will be given to aspects of resistance mechanism that are sharply targeted to inhibit the pest of interest and that is active only during the phase of plant growth when the protection is mostly needed. Tissue-specific gene promoters expressing the insecticidal proteins only in structures attacked by the pests are being developed to reduce risks to human health and to enhance the environmental safety of the new GM pest protected varieties.

The possible interference on food webs and on non-target organisms is another issue for careful consideration in tropical areas, especially if the varieties were developed aimed at the control of insects that are mainly pests in temperate regions. Different pest and non-target species occur in different parts of the world, and the management of the crop as a whole will also differ among different geographical locations. Thus, risk assessment results obtained in one country do not necessarily apply to another geographical region. Furthermore, a caseby-case approach is necessary and each GM plant and 
ecosystem must be looked at separately until there is sufficient experience to allow some extrapolation of the data and a wider view and interpretation of the environmental impacts.

Although the data presented in the literature regarding the impact of $B t$-crops on natural enemies and biodiversity are, in general, not conclusive, they tend to support the idea that transgenic resistance, by controlling primary pests without insecticides, could preserve natural biological controls acting upon secondary pests. However, more information is needed on three-trophic level interferences. Effort should be given to evaluate the utility of community diversity studies for risk assessment, particularly those broad studies that include all possible species without prior judgments of what will be the relevant data to approach key ecological questions. Furthermore, some impacts of GM crops will be scale dependent and this emphasizes the need to extend impact assessments beyond small-scale field experiments to farm scale, and eventually to commercial scale impact monitoring, to detect cumulative effects over time (Marvier 2001). This is consistent with the $\mathrm{CTNBio}^{2}$ regulation on post-commercialization monitoring of the Roundup Readyâ soybean.

Cross-pollination between sexually compatible crops and between GM crops and native/weedy species is a highly probable event. Hybridization between GM crops and weeds could produce more persistent weeds, especially through genetic modifications that confer selective advantage such as reduced herbivory. To fully assess these risks, studies are needed on the ecology of potential transgene recipient populations to assess the consequences of the transfer of the insect resistant trait. This issue will need to be examined carefully in the GM crop regulatory approval process.

Based on past experience with traditional plant breeding and on field and laboratory studies with molecular breeding, problems related to the development of resistance in the pest populations can be anticipated. Pests have historically overcome resistance introduced into crops by traditional breeding programmes, and adaptation to $B t$ toxins in some Lepidopteran species induced by the $B t$ biopesticide sprays has also been observed. Currently available data show that resistance to GM Bt crops will also occur. Furthermore, there are field observations showing that outbreaks of secondary pests will also occur. These two effects tend to be accentuated in tropical regions, as in Brazil, where more than one harvest of the same crop is often obtained in one year (for instance, for corn and soybean). Additionally, insect species usually have a larger number of generations in a year than in temperate regions. In this case, there will be strong selection pressure due to the presence of high toxin doses during the whole plant's life cycle. Thus, in tropical agriculture, the above indirect undesirable impacts become not only a threat but also highly probable events. The development and implementation of pest resistance management programs is imperative based on different strategies as crop management and improvement of biological control methods and the insertion of stacking or different resistance genes. The use of refuges planted with conventional cultivars to maintain susceptible genes in pest populations is one crop management alternative that has been used in the United States.

In assessing the environmental impact of genetically modified pest resistant crops we should acknowledge the fact that agriculture inevitably has an impact on the environment. We should also deal with the question of what is a reasonable trade-off between crop production, wildlife and the nonagriculture demands of the human population. It is especially relevant to take a baseline for comparison in the case of pest resistant crops, as current practices in conventional agriculture involves an intensive use of chemical pesticides. In this case, we must take into account the environmental damage caused by the use of pesticides in agriculture. In the United States alone, millions of birds and billions of insects, both harmful and beneficial are killed each year as a result of pesticide use (Pimentel \& Raven 2000).

Recent studies documenting negative impacts indicate that the risk assessment conducted internationally during the registration process for governmental approval of transgenic pest resistant crops may be overlooking some subtle and complex ecological effects on several trophic levels within and outside crop fields. In Brazil, the National Technical Biosafety Commission is evaluating two varieties of $B t$ corn for commercial release, and has approved applications for field tests of $B t$ cotton. Other varieties, including transgenic soybeans resistant to Anticarsia gemmatalis Hübner are in the pipeline. Little is known about the non-target species occurring in and around crop fields that might be affected by the use of this technology. Research in this area is urgently needed and should be encouraged by the governments through public research funding agencies.

\section{Acknowledgments}

This article originated from presentations made by the first and the last authors, in different symposia at the XIX Brazilian Congress of Entomology in Manaus, AM, June 1621, 2002. We thank Bonifácio P. Magalhães, Marcos R. de Faria, and Carl W. Schaefer for revising an early draft of the manuscript. The opinions expressed are those solely of the authors.

\section{Literature Cited}

Adamczyk Jr., J.J., L.C. Adams \& D.D. Hardee. 2001. Field efficacy and seasonal expression profiles for terminal leaves of single and double Bacillus thuringiensis toxin cotton genotypes. J. Econ. Entomol. 94: 1589-1593.

Adang, M.J., M.S. Brody, G. Cardineau, L.J. Petersen, G.B. Parker, S.A. McPherson, J. Wyman, S. Love, G. Reed, D. Biever \& D.A. Fischholf. 1993. The recontruction and expression of Bacillus thuringiensis cry III A gene in protoplants and potato plants. Plant Mol. Biol. 21: 1131-1145.

Alstad, D.N. \& D.A. Andow. 1995. Managing the evolution

${ }^{2}$ National Technical Commission on Biosafety, the leading biosafety regulatory body in Brazil. 
of insect resistance to transgenic plants. Science 268: 1894-1896.

Armer, C.A., R.E. Berry \& M. Kogan. 2000. Longevity of phytophagous heteropteran predators feeding on transgenic Bt-potato plants. Entomol. Exp. Appl. 95: 329333.

Arpaia, S. 1996. Ecological impact of $B t$-transgenic plants: 1. Assessing possible effects of cryIIIB toxin on honey bee (Apis mellifera L.) colonies. J. Genet. Breed. 50: 315-319.

Atkins, E.L., D. Kellum \& K.W. Atkins. 1981. Reducing pesticide hazards to honey bees: mortality prediction techniques and integrated management strategies. Leaflet 2883, revised edition. Riverside, Division of Agriculture Sciences, University of California, 24p.

Baker H.G. 1974. The evolution of weeds. Annu. Rev. Ecol. Syst. 5: 1-24.

Barton, K.A., R.H. Whiteley \& N.S. Yang. 1987. Bacillus thuringiensis d-entodoxin expressed in transgenic Nicotiana tabacum provides resistance to lepidopteran insects. Plant Physiol. 85: 1103-1109.

Bell, H.A., E.C. Fitches, R.E. Down, L. Ford, G.C. Marris, J.P. Edwards, J.A. Gatehouse \& A.M.R. Gatehouse. 2001. Effect of dietary cowpea trypsin inhibitor (CpTI) on the growth and development of the tomato moth Lacanobia oleracea (Lepidoptera: Noctuidae) and on the success of the gregarious ectoparasitoid Eulophus pennicornis (Hymenoptera: Eulophidae). Pest Manag. Sci. 57: 57-65.

Bhattacharya, R.C., N. Viswakarma, S.R. Bhat, P.B. Kirti \& V.L. Chopra. 2002. Development of insectresistant transgenic cabbage plants expressing a synthetic cryIA(b) gene from Bacillus thuringiensis. Curr. Sci. 83: 146-150.

Birch, A.N.E., I.E. Geoghegan, M.E.N. Majerus, J.W. McNicol, C. Hackett, A.M.R. Gatehouse \& J.A. Gatehouse. 1999. Tri-trophic interactions involving pest aphids, predatory 2-spot ladybirds and transgenic potatoes expressing snowdrop lectin for aphid resistance. Mol. Breed. 5: 75-83.

Bourget, D., J. Chaufaux, A. Micoud, M. Delos, B. Naibo, F. Bombarde, G. Marque, N. Eychenne \& C. Pagliari. 2002. Ostrinia nubilalis parasitism and the field abundance of non-target insects in transgenic Bacillus thuringiensis corn (Zea mays). Environ. Biosafety Res. 1: 49-60.

Brasileiro, A.C.M. \& V.T. de Carneiro. 1998. Manual de transformação genética de plantas. Embrapa SPI/ Cenargen, Brasília, 309p.
Bravo, A., S. Sarabia, L. Lopez, H. Ontiveros, C. Abarca, A. Ortiz, M. Ortiz, L. Lina, F.J. Villalobos, G. Peña, M.E. Nuñes-Valdez, M. Soberon \& R. Quintero. 1998. Characterization of cry genes in a mexican Bacillus thuringiensis strain collection. Appl. Environ. Microb. 64: 4965-4972.

Cannon, R.J.C. 2000. $B t$ transgenic crops: risks and benefits. Int. Pest. Manag. Rev. 5: 151-173.

Carpenter, J., A. Felsot, T. Goode, M. Hammig, D. Onstad \& S. Sankula. 2002. Comparative environmental impacts of biotechnology-derived and traditional soybean, corn, and cotton crops. Council for Agricultural Science and Technology. Iowa, USA. 189p.

Chakrabarti, S.K., A.D. Mandaokar, A. Shukla, D. Pattanayak, P.S. Naik, R.P. Sharma \& P.A. Kumar. 2000. Bacillus thuringiensis cry $1 \mathrm{Ab}$ gene confers resistance to potato against Helicoverpa armigera (Hubner). Potato Res. 43: 143-152.

Cheng, X.Y., R. Sardana, H. Kaplan \& I. Altosaar. 1998. Agrobacterium-transformed rice plants expressing synthetic cryIA(b) and cryIA(c) genes are highly toxic to striped stem borer and yellow stem borer. Proc. Natl. Acad. Sci. USA 95: 2767-2772

Choma, C.T., W.K. Surewicz, P.R. Carey, M. Pozsgay, T. Raynos \& H. Kaplan. 1990. Unusual proteolysis of the protoxin and toxin of Bacillus thuringiensis - structural implications. Eur. J. Biochem. 189: 523-527.

Christensen, M. 1989. A view of fungal ecology. Mycologia 81: 1-19.

Coombs, J.J., D.S. Douches, W.B. Li, E.J. Grafius \& W.L. Pett. 2002. Combining engineered (Bt-cry3A) and natural resistance mechanisms in potato for control of Colorado potato beetle. J. Am. Soc. Hort. Sci. 127: 6268 .

Cornu, D., J.C. Leplé. M. Bonadé-Bottino, A. Ross, S Augustin, A Delplanque, L. Jouanin \& G. Pilate. 1996. Expression of proteinase inhibitor and a Bacillus thuringiensis $\mathrm{d}$-endotoxin in transgenic poplars, p.131136. In Proceedings IUFRO Meeting on Somatic Cell Genetics and Molecular Genetic of Trees. Kluwer, Dordrecht, 287p.

Cui, J. \& J. Xia. 2000. Effects of Bt (Bacillus thuringiensis) transgenic cotton on the dynamics of pest population and their enemies. Acta Phytoph. Sin. 27: 145-52.

Dale, P.J., B. Clarke, \& E.M.G. Fontes. 2002. Potential for the environmental impact of transgenic crops. Nat. Biotechol. 20: 567-574.

Dogan, E.B., R.E. Berry, G.L. Reed \& P.A. Rossignol. 
1996. Biological parameters of convergent lady beetle (Coleoptera: Coccinellidae) feeding on aphids (Homoptera: Aphididae) on transgenic potato. J. Econ. Entomol. 89: 105-1108.

Duan, X., X. Li, Q. Xue, M. Abo-El-Saad, D. Xu \& R. Wu. 1996. Transgenic rice plants harboring an introduced potato proteinase inhibitor II gene are insect resistant. Nat. Biotechnol. 14: 494-496.

Ellstrand, N.C., H.C. Prentice, \& J. Hancock. 1999. Gene flow and introgression from domesticated plants into their wild relatives. Annu. Rev. Ecol. Sys. 30: 539-563.

ESA. 2001. Entomological Society of America. Symposium Summaries. 2001 ESA Annual Meeting. December 912, San Diego, California.

Fischholff, D.A., K.S Bowdish, F.J Perlak, P.G. Marrone, S.M. McCormick, J.G. Niedermeyer, D.A. Dean, K. Kusano-Katzmer, E.J. Mayer, D.E. Rochester, S.G. Rogers \& R.T. Finley. 1987. Insect tolerant transgenic tomato plants. BioTechnology 5: 807-813.

Fitter, A., J. Perrins \& M. Williamson. 1990. Weed probability challenged. BioTechnology 8: 473.

Fujimoto, H., K. Itoh, M. Yamamoto, J Kyozuka \& K. Shimamoto. 1993. Insect resistant rice generated by introduction of a modified o- endotoxin gene of Bacillus thuringiensis. BioTechnology 11: 1151-1155.

Gatehouse, A.M.R., G.M. Davison, C.A. Newell, A. Merryweather, W.D.O. Hamilton, E.P.J. Burgess, R.J.C. Gilbert \& J. A. Gatehouse. 1997. Transgenic potato plants with enhanced resistance to the tomato moth, Lacanobia oleracea, growthroom trials. Mol. Breed. 3: 49-63.

Gatehouse, J.A. \& A.M.R. Gatehouse. 2000. Genetic engineering of plants for insect resistance, p. 211-241. In J.E. Rechcigl \& N.A. Rechcigl (eds.). Biological and biotechnological control of insect pests. Lewis, Boca Raton, 374p.

Giles, K.L., R.L. Hellmich, C.T. Iverson \& L.C. Lewis. 2000. Effects of transgenic Bacillus thuringiensis corn grain on $B$. thuringiensis-susceptible Plodia interpunctella (Lepidoptera: Pyralidae). J. Econ. Entomol. 93: 1011-1016.

Girard, C., A.L. Picard-Nizou, E. Grallien, B. Zaccomer, L. Jouanin \& M.H. Pham-Delegue. 1998. Effects of proteinase inhibitor ingestion on survival, learning abilities and digestive proteinases of the honeybee. Transgenic Res. 7: 239-246.

Gould, F. 1991. The evolutionary potential of crop pests. Am. Sci. 79: 496-507.
Gould, F. 1998. Sustainability of transgenic insecticidal cultivars: integrating pest genetics and ecology. Annu. Rev. Entomol. 43: 701-726.

Greenpeace Report. 2002. A summary of research on the environmental impact of Bt cotton in China. D. Xue (ed.). Published by Greenpeace, 26p.

Groot, A.T. \& M. Dicke. 2002. Insect-resistant transgenic plants in a multi-trophic context. Plant J. 31: 387-406.

Hails, R.S., M. Reeds, D.D. Kohn \& M.J. Crawley. 1997. Burial and seed survival in Brassica napus subsp. Oleifera and Sinapis arvensis including a comparison of transgenic and non-transgenic lines of the crop. Proc. R. Soc. Lond. Ser. B, Biol. Sci. 264: 1-7.

Head, G., J.B. Surber, J.A. Watson, J.W. Martin \& J.J. Duan. 2002. No detection of cry1Ac protein in soil after multiple years of transgenic $B t$ cotton (Bollgard) use. Environ. Entomol. 31: 30-36.

Hilbeck, A. 2002. Transgenic host plant resistance and nontarget effects, p. 167-185. In D.K. Letourneau \& B.E. Burrows (eds.). Genetically engineered organisms. Assessing environmental and human health effects. CRC Press, Boca Raton, FL, 438p.

Hilbeck, A., M. Baumgartner, P.M. Fried \& F. Bigler. 1998a. Effects of transgenic Bacillus thuringiensis cornfed prey on mortality and development time of immature Chrysoperla carnea (Neuroptera: Chrysopidae). Environ. Entomol. 27: 480-487.

Hilbeck A, W.J. Moar, M. Pusztai-Carey, A.M. Filippini \& F. Bigler. 1998b. Toxicity of Bacillus thuringiensis cry $1 \mathrm{Ab}$ toxin to the predator Chrysoperla carnae. Environ. Entomol. 27:1255-63.

Hilbeck, A., W.J. Moar, M. Pusztai-Carey, A. Filippini \& F. Bigler. 1999. Prey-mediated effects of cry $1 \mathrm{Ab}$ toxin and protoxin and cry $2 \mathrm{~A}$ protoxin on the predator Chrysoperla carnea. Entomol. Exp. Appl. 91: 305-316.

Hilder, V.A., K.S. Powell, A.M.R. Gatehouse, J.A. Gatehouse, L.N. Gatehouse, Y. Shi, W.D.O. Hamilton, A. Merryweather, C. Newell, J.C. Timans, W.J. Peumans, E.J.M. Van Damme \& B. Boulter. 1995. Expression of snowdrop lectin in transgenic tobacco plants results in added protection against aphids. Transgenic Res. 4: 18-25.

Hoy, C.W., J. Feldman, F. Gould, G.G. Kennedy, G. Reed \& J.A. Wyman. 1998. Naturally occurring biological controls in genetically engineered crops, p. 185-205. In P. Barbosa (ed.). Conservation biological control. Academic Press, London, 396p.

Ishimoto, M., J. Sato, M.J. Chrispeels \& K. Kitamura. 
1996. Bruchid resistance of transgenic azuki bean expressing seed alpha-amylase inhibitor in the common bean. Entomol. Exp. Appl. 79: 309-315.

James, C.A. 2001. Global review of commercialized transgenic crops, 2001. ISAAA Briefs No. 24. Preview ISAAA, Ithaca, NY. http://www.isaaa.org/publications/ briefs/Brief_24.htm

James, R.R., J.C. Miller \& B. Lighthart. 1993. Bacillus thuringiensis var. kurstaki affects a beneficial insect, the cinnabar moth (Lepidoptera: Archtiidae). J. Econ. Entomol. 86: 334-339.

Jansen, S., A. vanVliet, C. Dickburt, L. Buysse, C. Piens, B. Saey, A. de Wulf, V. Gossele, A. Paez \& E. Gobel. 1997. Transgenic corn expressing a cry $9 \mathrm{C}$ insecticidal protein from Bacillus thuringiensis protected from European corn borer damage. Crop Sci. 37: 1616-1624.

Jelenkovic, G, S. Billings, Q. Chen, J. Lashomb, G. Hamilton \& G. Ghidiu. 1998. Transformation of eggplant with synthetic cryIIIA gene produces a high level of resistance to the Colorado potato beetle. J. Am. Soc. Hort. Sci. 123: 19-25.

Johnson, K.S., J.M. Scriber, J.K. Nitao \& D.R. Smitley. 1995. Toxicity of Bacillus thuringiensis var. kurstaki to three non-target Lepidoptera in field studies. Environ. Entomol. 24: 288-297.

Jouanin L., M. Bonade-Bottino, C. Girard \& G. Morrot. 1998. Transgenic plants for insect resistance. Plant Sci. 131: 1-11.

Kogan, M. 1986. Plant defense strategies and host-plant resistance, p. 83-134. In M. Kogan (ed.), Ecological theory and integrated pest management. John Wiley \& Sons, New York, 362p.

Kota, M., H. Daniell, S. Varma, S.F. Garczynski, F. Gould \& W.J. Moar. 1999. Overexpression of the Bacillus thuringiensis $(B t)$ cry2Aa2 protein in chloroplasts confers resistance to plants against susceptible and $B t$-resistant insects. Proc. Natl. Acad. Sci. USA 96: 1840-1845.

Koziel, M.G., G.L Beland, C. Bowman, N. B. Carozzi, R. Crenshaw, L. Crosslaind, J. Dawson, N. Desai, M. Hill, M. Kadwell, K. Launis, K. Lewis, D. Maddox, D. Mc Pherson, M.R. Meghiji, E. Merlin, R. Rhodes, G.W. Warren, M. Wright \& S.V. Evola. 1993. Field perfomance of elite transgenic corn plants expressing insecticidal protein derived from Bacillus thuringiensis. BioTechnology 11: 194-200.

Kumar, P.A., A. Mandaokar, K. Sreenivasu, S.K. Chakrabarti, S. Bisaria, S.R. Sharma, S. Kaur \& R.P. Sharma. 1998. Insect-resistant transgenic brinjal plants. Mol. Breed. 4: 33-37.
Lacey, L.L. \& H.K. Kaya. 2000. Field manual of techniques in invertebrate pathology. Dordrecht, Kluwer, 911p.

Leplé J.C., M. Bonadé-Bostino, S. Augustin, G. Pilate, V.D. Le Tân, A. Delplanque, D. Cornu \& L. Jouanin. 1995. Toxicity to Chrysomela tremulae (Coleoptera: Chrysomelidae) of a transgenic poplars expressing a cysteine proteinase inhibitor. Mol. Breed. 1: 319-328.

Lewis, W.J. \& K. Takasu. 1990. Use of learned odours by a parasitic wasp in accordance with host and food needs. Nature 348: 635-636.

Losey, J. E., L.S. Rayor \& M.E. Carter. 1999. Transgenic pollen harms monarch larvae. Nature 399: 214.

Lozzia, G.C. 1999. Biodiversity and structure of ground beetle assemblages (Coleoptera Carabidae) in Bt corn and its effects on non target insects. Boll. Zool. Agraria Bachiocoltura 31: 37-58.

Lozzia, G.C., C. Furlanis, B. Manachini \& I.E. Rigamonti. 1998. Effects of Bt corn on Rhopalosiphum padi L. (Rhynchota Aphididae) and its predator Chrysoperla carnea Stephen (Neuroptera Chrysopidae). Boll. Zool. Agraria Bachicoltura 30: 153-164.

Luby, J.J. \& R.F. McNichol. 1995. Gene flow from cultivated to wild raspberries in Scotland: developing a basis for risk assessment for testing and deployment of transgenic cultivars. Theor. Appl. Genet. 90: 1133-1137.

Malone, L.A., E.P.J. Burgess, H.S. Gatehouse, C.R. Voisey, E.L. Tregidga \& B.A. Philip. 2001. Effects of ingestion of a Bacillus thuringiensis toxin and a trypsin inhibitor on honeybee fligth activity and longevity. Apidologie 32: 57-68.

Mandaokar, A.D., R.K. Goyal, A. Shukla, S. Bisaria, R. Bhalla, V.S. Reddy, A. Chaurasia, R.P. Sharma, I. Altosaar \& P.A. Kumar. 2000. Transgenic tomato plants resistant to fruit borer (Helicoverpa armigera Hübner). Crop Prot. 19: 307-312.

Maqbool, S.B., S. Riazuddin, N.T. Loc, A.M.R. Gatehouse, J.A. Gatehouse \& P. Christou. 2001. Expression of multiple insecticidal genes confers broad resistance against a range of different rice pests. Mol. Breed. 7: 85-93.

Marfa, V., E. Mele, R. Gabarra, J.M. Vassal, E. Guiderdoni \& J. Messeguer. 2002. Influence of the developmental stage of transgenic rice plants (cv. Senia) expressing the cry $1 \mathrm{~B}$ gene on the level of protection against the striped stem borer (Chilo suppressalis). Plant Cell Rep. 20: 1167-1172.

Marvier, M. 2001. Ecology of transgenic crops: Genetically engineered plants might generate weed problems and 
affect non-target organisms, but measuring the risk is difficult. Am. Scien. 89: 160-167.

McBride, K.E., Z. Svab, D.J. Schaaf, P.S. Hoogan, D.M. Stalker \& P. Maliga. 1995. Amplification of a chimeric Bacillus gene in chloroplasts leads to an extraordinary level of an insecticidal preotein in tobacco. BioTechnology 13: 362-365.

McCown, B.H., D.E. McCabe, D.R. Russll, D.J. Robison, K.A. Barto \& K.F. Rafffa. 1991. Stable tranformation of Populus and incorporation of pest resistance by electric discharge particle acceleration. Plant Cell Rep. 9: 590-594.

Miller, J.C., 1990. Field assessment of the effects of a microbial pest control agent on non-target Lepidoptera. Am. Entomol. 36: 1355-139.

Munkvold, G.P., R.L. Hellmich \& L.G. Rice. 1999. Comparison of fumonisin concentration in kernels of transgenic $B t$ corn hybrids and nontransgenic hybrids. Plant Dis. 83: 130-138.

NRC - National Research Council. 2000. Genetically Modified Pest-Protected Plants: Science and Regulation. National Academy Press. Washington, DC, 263p.

Obrycki, J.J., J.E. Losey, O.R. Taylor \& L.C.H. Jesse. 2001. Transgenic insecticidal corn: beyond insecticidal toxicity to ecological complexity. BioScience 51: 353-361.

Orr, D.B. and D.A. Landis. 1997. Oviposition of European corn borer (Lepidoptera: Pyralidae) and impact of natural enemy populations in transgenic versus isogenic corn. J. Econ. Entomol. 90: 905-909.

Peferoen, M. 1992. Engineering of insect-resistant plants with Bacillus thuringiniesis crystal protein genes. Biotech. Agric. 7: 135-153.

Peferoen, M. 1997. Insect control with transgenic plants expressing Bacillus thuringiensis crystal proteins, p. 2148. In N. Carrozi \& M.G. Coziel (eds.), Advances in insect control: the role of transgenic plants. Taylor and Francis, London, 301p.

Perlak, F.J., R.L. Fuchs, D.A. Dean, S.L. McPherson \& D.A. Fishholff. 1991. Modification of the coding sequence enhances plant expression of insect control protein genes. Proc. Natl. Acad. Sci. USA 88: 3324 3328.

Perlak, F.J., R.W. Deaton, T.O. Armstrong, R.L. Fuchs, S.R. Sims, J.T. Greenplate \& D.A. Fishholff. 1990. Insect resistant cotton plants. BioTechnology 8: 939-943.

Perlak, F.J., T.B. Stone, Y.M. Muskopf, N. Eagan, R.T. Roush, C.K. Shewmaker, A. Jones, J.V. Oakes \& K.E.
McBride. 1993. Geneticaly improved potatoes: protection from damage by Colorado potato beetles. Plant Mol. Biol. 22: 313 -321.

Picard-Nizou, A.L., R. Grison, L. Olsen, C.P.G. Arnold \& M.H. Pham-Delegue. 1997. Impact of proteins used in plant genetic engineering: toxicity and behavioral study in the honeybee. J. Econ. Entomol. 90: 1710-1716.

Pilcher, C.D., J.J. Obrycki, M.E. Rice \& L.C. Lewis. 1997. Preimaginal development, survival, and field abundance of insect predators on transgenic Bacillus thuringiensis corn. Environ. Entomol. 26: 445-454.

Pimentel, D.S. \& P.H. Raven. 2000. Bt corn pollen impacts on non-target Lepidoptera: assessment of effects in nature. Proc. Natl. Acad. Sci. USA 97: 8198-8199.

Price, P. W. 1997. Insect ecology. John Wiley \& Sons, New York, NY, 874p.

Price, P.W., C.E. Bouton, P. Gross, B.A. McPherson, J.N. Thompson \& A.E. Weis. 1980. Interactions among three trophic levels: interactions between insect herbivores and natural enemies. Annu. Rev. Ecol. Syst. 11: 41-65.

Ramachandran, S., G.D. Buntin, J.N. All, P.L. Raymer \& C.N. Stewart. 1998. Greenhouse and field evaluations of transgenic canola against diamondback moth, Plutella xylostella, and corn earworm, Helicoverpa zea. Entomol. Exp. Appl. 88: 17-24.

Ramachandran, S., G.D. Buntin, J.N. All, P.L. Raymer \& C.N. Stewart. 2000. Integrated pest management: Intraspecific competition of an insect-resistant transgenic canola in seed mixtures. Agron. J. 92: 368-374.

Raymond, M., A. Callaghan, P. Fort \& N. Pasteur. 1991. Worldwide migration of amplidied insecticide resistance genes in mosquitoes. Nature 350: 151-153.

Regal, P.J. 1988. The adaptative potential of genetically engineered organisms in nature. Trends Ecol. Evol. 3: S36-S38.

Regal. P.J. 1994. The true meaning of "exotic species" as a model for genetically engineered organisms. Experientia 49: 225-229.

Rice, M.E. \& C.D. Pilcher. 1998. Potential benefits and limitations of transgenic $B t$ corn for management of the European corn borer (Lepidoptera: Crambidae). Am. Entomol. 44: 74-78.

Rico, E., V. Ballester \& J.L. Mensua. 1998. Survival of two strains of Phthorimaea operculella (Lepidoptera: Gelechiidae) reared on transgenic potatoes expressing a Bacillus thuringiensis crystal protein. Agronomie 18: 151-155. 
Riddick, E.W. \& P. Barbosa. 2000. Cry3A-intoxicated Leptinotarsa decemlineata (Say) are palatable prey for Lebia grandis Hentz. J. Entomol. Sci. 35: 342-346.

Riddick, E.W., G. Diveli \& P. Barbosa. 2000. Season-long abundance of generalist predators in transgenic vs. nontransgenic potato fields. J. Entomol. Sci. 35: 349-359.

Saxena, D. \& G. Stotzky. 2000. Insecticidal toxin from Bacillus thuringiensis is released from roots of transgenic $B t$ corn in vitro and in situ. FEMS Microbiol. Ecol. 33: 35-39.

Saxena, D., S. Flores \& G. Stotzky. 1999. Insecticidal toxin in root exudates from $B t$ corn. Nature 402: 480.

Schuler, T.H. 2000. The impact of insect resistant GM crops on populations of natural enemies. Antenna 24: 59-65.

Schuler, T.H., G.M. Poppy \& I. Denholm. 2000. Recommendations for assessing effects of GM crops on non-target organisms, p.1221-1228. BCPC Conference - Pests and Diseases 2000, Harpenden, UK, IACRRothamsted.

Schuler, T.H., G.M. Poppy, R.P.J. Potting, I. Denholm \& B.R. Kerry. 1999a. Interactions between insect tolerant genetically modified plants and natural enemies. BCPC Symp. Proc. 72: 197-202.

Schuler, T.H., R.P.J. Potting, I. Denholm \& G.M. Poppy. 1999b. Parasitoid behaviour and $B t$ plants. Nature 400 : 825-826.

Sears, M.K., R.L. Hellmich, E. Stanley-Horn, K. Oberhauser, J.M. Pleasants, H.R. Mattila, B.D. Siegfried \& G.P. Dively. 2001. Impact of $B t$ corn pollen on monarch butterfly populations: A risk assessment. Proc. Natl. Acad. Sci. USA 98: 11937-11942.

Selvapandiyan, A., V.S. Reddy, P.A. Kumar, K.K. Tewari \& R.K. Bhatnagar. 1998. Transformation of Nicotiana tabacum with a native cry1Ia5 gene confers complete protection against Heliothis armigera Mol. Breed. 4: 473-478.

Shade, R.E., H.E. Schroeder, J.J. Pueyo, L.M. Tabe, L.L. Murdock, T.J.V. Higgins \& M.J. Chrispeels. 1994. Transgenic pea seeds expressing the alpha-amylase inhibitor of the common bean are resistant to bruchid beetles. Biotechnology 12: 793-796.

Shatters, Jr., R.G. 2000. Environmental impact of biotechnology, p. 281-302. In J.E. Rechcigl \& N.A. Rechcigl (eds.), Biological and biotechnological control of insect pests. Lewis Publishers, Boca Raton, FL, USA, $374 \mathrm{p}$.

Shelton, A.M., J.Z. Zhao \& R.T. Roush. 2002. Economic, ecological, food safety, and social consequences of the deployment of $B t$ transgenic plants. Annu. Rev. Entomol. 47: 845-881.

Shroeder, H.E., S. Gollasch, A. Moore, L.M. Tabe, S. Craig, D.C. Hardie, M.J. Chrispeels, D. Spencer \& T.J.V. Higgins. 1995. Bean alpha-amylase inhibitor confers resistance to pea weevil (Bruchus pisorum) in transgenic peas (Pisum sativum L.). Plant Physiol. 107: 1233-1239.

Snow, A.A. 2002. Transgenic crops - why gene flow matters. Nature Biotech. 20: 452.

Stewart Jr., C.N., J.N. All, P.L. Raymer \& S. Ramachandran. 1997. Increased fitness of transgenic insecticidal rapeseed under insect selection pressure. Mol. Ecol. 6: 773-779.

Stewart. C.N., M.J. Adang, J.N. All, H.R. Boerma, G. Cardineaux, D. Tucker \& W.A. Parrot. 1996a. Genetic tranformation recovery, and characterization of fertile soybean transgenic for a synthetic Bacillus thuringiensis cry IA (c) gene. Plant Physiol. 112: 121-129.

Stewart, C.N., M.J. Adang, J.N. All, P.L. Raymer, S. Ramachandran \& W.A. Parrott. 1996b. Insect control and dosage effects in transgenic canola containing a synthetic Bacillus thuringiensis cry IAc gene. Plant Physiol. 112: 115-120.

Stotzky, G. 2000. Persistence and biological activity in soil of insecticidal proteins from Bacillus thuringiensis and of bacterial DNA bound on clays and humic acids. J. Environ. Qual. 29: 691-705.

Stotzky, G. 2002. Release, persistence, and biological activity in soil of insecticidal proteins from Bacillus thuringiensis, p. 187-222. In D.K. Letourneau \& B.E. Burrows (eds.), Genetically engineered organisms. Assessing environmental and human health effects. CRP Press, Boca Raton, FL, 438p.

Strizhov, N., M. Keller, J. Mathur, K. Koncz-Kalman, D. Bosch, E. Prudovsky, J. Schell, B. Sneh, C. Koncz \& A. Zilberstein. 1996. A synthetic cry IC gene, encoding a Bacillus thuringiensis d-endotoxin, confers Spotoptera resistance in alfalfa and tobacco, Proc. Nalt.Acad Sci. USA 93: 1512-15017.

Tabashnik, B.E. 1994. Evolution of resistance to Bacillus thuringiensis. Annu. Rev. Entomol. 39: 47-79.

Tanada, Y. \& H.K. Kaya. 1993. Insect pathology. Academic Press, San Diego, 666p.

Tiedje, J.M., R.K. Colweell, Y.L. Grossman, R.E. Hodson, R.E. Lenski, R.N. Mack \& P.J. Regal. 1989. The planned introduction of genetically engineered 
organisms: Ecological considerations and recommendations. Ecology 70: 298-315.

US EPA (US Environmental Protection Agency). 2000. Sets of scientific issues being considered by the Environmental Protection Agency regarding Bt plantpesticides risk and benefit assessments. SAP Report. 2000-07. FIFRA Scientific Advisory Panel Meeting, October 18-20, 2000.

Vaeck, M., A. Reynaerts, H. Hofte, S. Jansens, M. DeBeuckleer, C. Dean, M. Zabeau, M. Van Montagu \& J. Leemans. 1987. Transgenic plants protected from insect attack. Nature 327: 33-37.

Vinson, S.B. 1976. Host selection by insect parasitoids. Ann. Rev. Entomol. 21: 109-134.

Whaley, W.H., J. Anhold \& G.B. Schaalje. 1998. Canyon drift and dispersion of Bacillus thuringiensis and its effects on selected non-target lepidopterans in Utah. Environ. Entomol. 27: 539-548.

Williams, S., L. Friedrich, S. Dincher, N Carozzi, H. Kessmann, E. Ward \& J. Ryals. 1993. Chemical regulation of Bacillus thuringiensis delta-endotoxin expression in transgenic plants. BioTechnology 7: 194200.

Williamson, M. 1993. Invaders, weeds and the risk from genetically manipulated organisms. Experientia 49: 219224.

Williamson, M., J. Perrings \& A. Fitter. 1990. Releasing genetically engineered plants: present proposals and possible hazards. Trends Ecol. Evol. 5: 417-419.
Wraight, C.L., A.R. Zangerl, M.J. Carroll \& M.R. Berenbaum. 2000. Absence of toxicity of Bacillus thuringiensis pollen to black swallowtails under field conditions. Proc. Natl. Acad. Sci. USA 97: 7700-7703.

Wunn, J., A Kloti, PK. Burkhardt, G.C.C. Biswas, K. Launis, V.A Inglesias \& I Potrykus. 1996. Transgenic indica rice breeding line IR 58 expressing a synthetic cry A (b) gene from Bacillus thuringiensis provides effective pest control. BioTechonology 14: 171- 176.

Xu, D.P., Q.Z. Xue, D. McElroy, Y. Malwal, V.A. Hilder \& R. Wu. 1996. Constitutive expression of a cowpea trypsin-inhibitor gene, CpT1, in transgenic rice plants confers resistance to 2 major rice insect pests. Mol. Breed. 2: 167-173.

Zangerl, A.R., D. McKenna, C.L. Wraight, M. Carrol, P. Ficarello, R. Warner \& M.R. Berenbaum. 2001. Effects of exposure to event 176 Bacillus thuringiensis corn pollen on monarch and black swallowtail caterpillars under field conditions. Proc. Natl. Acad. Sci. USA 98: 11908-11912.

Zhao, J.Z., Y.X. Li, H.L. Collins, J. Cao, E.D. Earle \& A.M. Shelton. 2001. Different cross-resistance patterns in the diamondback moth (Lepidoptera: Plutellidae) resistant to Bacillus thuringiensis toxin crylC. J. Econ. Entomol. 94: 1547-1552.

Zwahlen, C., W. Nentwig, F. Bigler \& A. Hillbeck. 2000. Tritrophic interactions of transgenic Bacillus thuringiensis corn, Anaphothrips obscurus (Thysanoptera: Thripidae), and the predator Orius majusculus (Heteroptera: Anthocoridae). Environ. Entomol. 29: 846-850. 